\title{
The Impact of Service Quality on Students' Satisfaction and the Word-of-Mouth: The Case of the University of Rijeka Departments
}

\author{
Dunja Meštrović \\ Faculty of Tourism and Hospitality Management in Opatija, Croatia
}

\begin{abstract}
The purpose of this paper is to determine the impact of service quality perceived by science, technology, engineering and mathematics (STEM) and informationcommunication (IC) students of the University ofRijeka Departments on students' satisfaction and positive word-of-mouth. Based on the extensive literature review, the survey method was used to explore the relationships between the following variables: service quality, students' satisfaction, and word-of-mouth. The data were collected through an online self-administrated structured questionnaire administered to undergraduate and graduate STEM and IC students of the University of Rijeka Departments using Google Docs Forms. The findings provide some important insights into how the service quality impacts the students' satisfaction and word-of-mouth, in a Croatian higher education context. A high positive significant impact of service quality on students' satisfaction and word-of-mouth clearly indicates that it is an imperative for higher education sector. Based on the results and remarks of this study improvements can be planned and concluded across all dimensions. Policy makers in the industry in general and in the higher education sector, in particular, may benefit from the findings of this study.
\end{abstract}

Keywords: higher education, research, service quality, students' satisfaction, word-ofmouth

JEL classification: M310, I23

Acknowledgments: This work has been fully supported by the University of Rijeka under the project Students' satisfaction and attitudes towards service quality and efficiency in study: a study conducted among STEM and IC students of the University of Rijeka Departments, project number 2015/46.

\section{Introduction}

In today's competitive higher education (HE) marketplace, where students have many options and choices available, factors that enable higher education institutions (HEls) to attract and retain students should be seriously considered. The importance of attracting and retaining students in Science, Technology, Engineering and Mathematics (STEM) and Information-communication (IC) study area is of great significance due to the fact that STEM and IC expertise is needed in all modern and knowledge-based societies since technological innovations are the primary driver for economic growth (EC, 2015 and CIC, 2014). DeShields Jr. et al. (2005) proposed a strategy to improve students' retention through high service quality (SQ). Providing a high level of SQ represents a critical determinant of competitiveness and success factor in the services sector (Lewis, 1989), the most powerful competitive weapon for most service organizations (Berry et al., 1988). High SQ improves customer satisfaction 
(CS) (Johns et al., 2004), while SQ and CS are significant determinants of customer loyalty (CL) (Cristobal et al., 2007; Cronin et al., 2000; Imrie et al., 2000) and loyal customers spread favorable word-of-mouth (WOM) communication (Reichheld and Sasser Jr., 1990; Athiyaman, 1997). According to Reichheld (2003), intention to spread positive WOM is the only indicator needed for companies to grade and evaluate their CL. In the wider marketing context, the premise that high SQ results in improvements of CS and CL should be considered amongst fundamentals for the sustainability of STEM and IC HEls.

The purpose of this paper is to determine the impact of SQ perceived by STEM and IC students of the University of Rijeka Departments' (UniRi Depts.) on students' satisfaction (SS) and the most important determinant of students' loyalty: positive WOM, that is part of a larger study that analyses students' satisfaction and attitudes towards service quality and efficiency in study.

The CS and its determinant factors have been key issues in the marketing and management literature, being extensively studied over the past decades. However, the impact of SQ on SS and loyalty in the STEM and IC HE sector is a rather new subject and it has been barely emphasized in the literature. Even though there are many studies on SQ, SS and loyalty in HE industry, research on STEM (Swaid, 2014) and IC HE regarding these issues is rather limited. Moreover, to the best of author's knowledge, research in this field with evidence from Croatia is extremely scarce. The essence of this study that points out its originality is the fact that this is believed to be the first study of this kind carried out among students at the University of Rijeka. Additionally, the fact that the questionnaire can be utilized in most HE establishments can be considered as an important value of this work.

After a brief explanation of the suggested model and proposed hypotheses, the research hypotheses are proposed and the research methodology is explained. The analysis of the collected data and testing of the hypotheses are followed by the discussion of the main results and by a brief conclusion that refers to the similar studies and indicates the limitations of the study, with a proposal for future research.

\section{Methodology}

A framework was developed based on the extensive literature review, with the following variables: SQ, SS and WOM, shown in Figure 1, proposing hypotheses about their relationship. It was decided to develop a new measurement tool since many existing surveys do not include all important topics concerning the specific conditions of studying in STEM and IC study area at the UniRi Depts.

The survey method was used to explore the relationships of the study. The data were collected through an anonymous online self-administrated, structured questionnaire using a five-point Likert scale ranged from strongly disagree (1) to strongly agree (5). Perceived $S Q$ dimensions were measured using a multiple-item scale adapted from Legčević (2014),SS at an institutional level that covers most aspects of students' life was assessed by four items adapted from Seng and Ling (2013), likelihood of saying positive things about the faculty, recommending it to a friend or a family member and probability of making the same choice if the student had to do it all over again were used as indicators of positive WOM, followed by questions concerning reasons for choosing the study program, efficiency in studying, demographic characteristics and an open question enabling participants to add their suggestions. 
Figure 1

SQ-SS-WOM Model

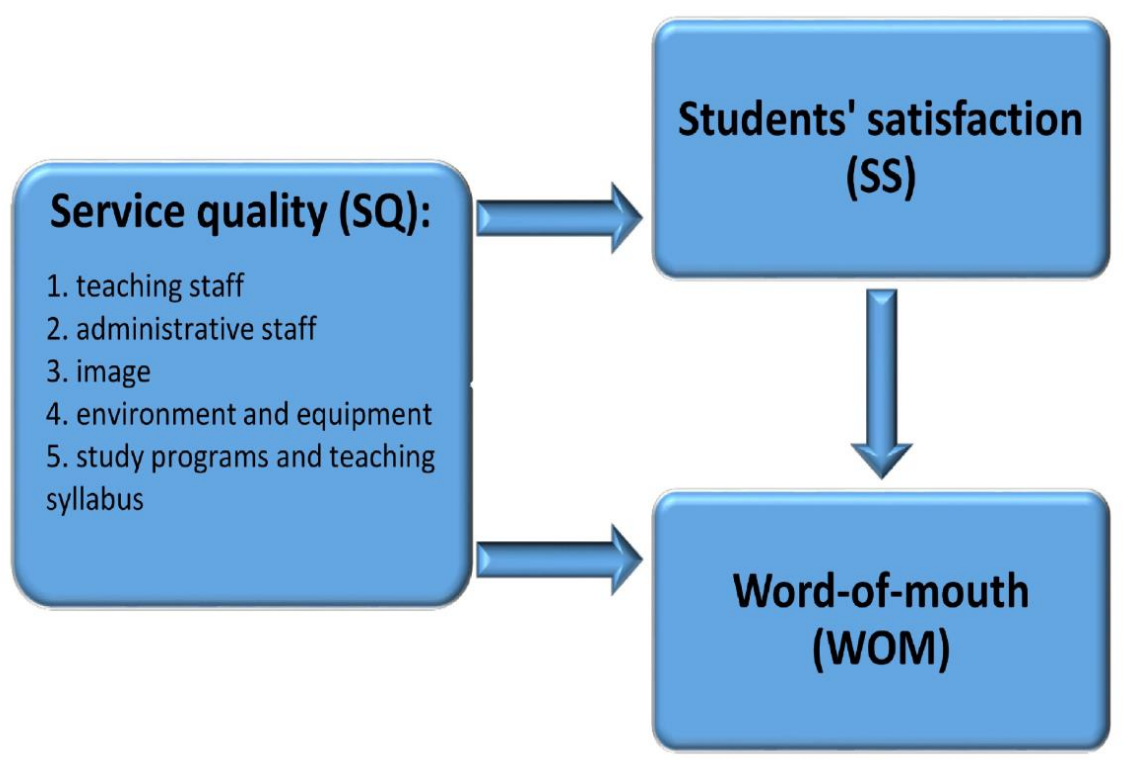

Source: Author's illustration adapted from Legčević (2014)

The pre-tested questionnaire was administered to undergraduate and graduate STEM and IC students of the UniRi Depts. using Google Docs Forms. The survey was conducted in the period of two months during the middle of summer semester of the academic year 2014/2015. Amongst 873 students enrolled and surveyed in this study, 214 usable questionnaires returned, that is a response rate of $24,51 \%$ what can be considered as an adequate sample size, since other scale developers in the marketing area used a sample size of 200 to analyze group data (Parasuraman et al., 1988; Marković, 2006). Table 1 summarizes the profile of respondents.

Table 1

Respondents' Profile

\begin{tabular}{llll}
\hline & Sample demographics & Frequency & $\%$ \\
\hline Gender & Male & 74 & 34,58 \\
\hline Age & Female & 140 & 65,42 \\
\hline & $<21$ & 50 & 23,36 \\
\hline Study program & $21-23$ & 140 & 48,60 \\
\hline \multirow{2}{*}{ Tuition } & Undergraduate & 60 & 28,04 \\
\hline & Graduate & 142 & 66,36 \\
\hline Average grade & MSOS* grant & 72 & 33,64 \\
\hline & Students paying tuition fees & 184 & 85,98 \\
\hline & Excellent (5) & 30 & 14,02 \\
\hline & Very good (4) & 39 & 18,22 \\
\hline & Good (3) & 99 & 46,26 \\
\hline
\end{tabular}

Note: *MSOS - Ministry of Science, Education and Sports of the Republic of Croatia Source: Author 
For the data analysis, Statistica12.7 software was used. After confirming the reliability and acceptability of the measurement model, Partial Least Squares Structural Equation Modeling using SmartPLS 3.0 software was applied to examine the impact of SQ on SS and on students' intention to spread positive WOM, as an appropriate method that produces latent variable scores that can be used to predict a model, placing minimal limitations on the distribution characteristics and sample size (Hair et al., 2010).

\section{Results}

According to the descriptive statistics generated, overall satisfaction (mean 3,331 ) and intention to recommend (mean 3,553) is high and the mean scores for all statements related to five SQ dimensions (Legčević, 2014), i.e., teaching staff, administrative staff, image, environment and equipment and study program and teaching syllabus were above the value of 3.

Table 2

Results of Data Analysis

\begin{tabular}{llllll}
\hline Structural Equation & $\begin{array}{l}\text { Path } \\
\text { coefficient }\end{array}$ & $\begin{array}{l}\text { Discriminant } \\
\text { validity }\end{array}$ & STDEV & T & P \\
\hline SQ $\rightarrow$ SS & 0,766 & 0,737 & 0,027 & 29,256 & 0,000 \\
\hline SQ $\rightarrow$ WOM & 0,690 & 0,652 & 0,057 & 0,228 & 0,819 \\
\hline SS $\rightarrow$ WOM & 0,861 & 0,884 & 0,049 & 17,873 & 0,000 \\
\hline
\end{tabular}

Source: Author

From the analysis of the path coefficients using a two-tailed t-test with a significance level of $5 \%$ of each structural equation presented in Table 2, it was found that all path coefficients are significant (i.e. larger than 1,96) except "SQ WOM" linkage $(0,228)$. SS has a significant direct positive impact on WOM and that perceived SQ has a positive direct impact on SS and indirect positive impact on WOM through SS (according to indirect effects analysis resulting in path coefficient 0,660 with statistically significant T value of 13,600 at 0,05 confidence level).

\section{Discussion}

This research aimed to study the impact of $S Q$ dimensions on SS and on positive WOM for STEM and IC students in Croatian HE context. The results are consistent with similar studies confirming a direct positive relationship between SQ and SS (Hasan et al., 2009; Malik et al., 2010; Ham and Hayduk, 2003; Bigne et al., 2003), indirect positive relationship between SQ and WOM through SS (Dado et al., 2012 and Aljumaa, 2013) and direct positive relationship between SS and positive WOM behaviors, (Reichheld et al., 1990; Athiyaman, 1997; Dado et al., 2012), which plays an important role in the decision-making process and makes an effective way for an $\mathrm{HEl}$ to recruit new students. In addition, the study examined the relationships among these variables and provided statistical evidence for their significance.

The findings can also be useful to the HEls' management to quantify SQ and to show the path for future practices for HE sector. Since data analysis resulted in high reliability and identifies strengths and weaknesses across SQ dimensions, HEls can monitor SS as one of the key elements in creating and developing SQ as a key factor to attract, educate and retain STEM and IC students.

The study was carried out among STEM and IC students of the UniRi Depts. only, what represents its limitation and its outcomes could not be generalized. The author 
kindly suggests further research to cover a wider range of universities in Croatia, including private establishments, with study programs in STEM and IC study area, and also in other branches of science study areas, so that a model with more conformity will be produced for planning to improve educational $S Q$.

\section{Conclusion}

Based on the results and remarks of this study improvements can be planned across all dimensions of educational service quality. Although satisfaction is more important determinant of future behavioral intentions (i.e. positive WOM), higher education service quality should not be neglected due to its positive impact on behavioral intentions. Policy makers in the services industry in general and in the HE sector in particular, may benefit from the findings of this study.

Due to the limitations of the study, its results should not be generalized. Further research is required to consider the perspectives of other stakeholders in HE. Finally, research is needed to extend our understanding of the importance of service quality evaluation, students' satisfaction and positive word-of-mouth what seems to be rather important and rich area for further investigation.

\section{References}

1. Aljumaa, A. (2013), "Investigating the Mediating Effect of Customer Satisfaction in the Service Quality-Word of Mouth relationship", International Journal of Business and Management Invention, Vol. 3 No. 3, pp. 40-45.

2. Athiyaman, A. (1997), "Linking student satisfaction and service quality perceptions: the case of university education", European Journal of Marketing, Vol. 31 No. 7, pp. 528540.

3. Berry, L.L., Parasuraman, A. Zeithaml, V.A. (1988), "The service - quality puzzle", Business Horizons, Vol. 31 No. 5, pp. 35-43.

4. Bigne, E., Moliner, M. A., Sanchez, J. (2003), "Perceived quality and satisfaction in multi service organizations: The case of Spanish public services", The Journal of Services Marketing, Vol. 17 No. 4, pp. 420-442.

5. Council of Independent Colleges, CIC (2014), „Strengthening the STEM Pipeline: The Contributions of Mid and Small Independent Colleges", available at: http://www.cic.edu/Research-and-Data/Research-Studies/Documents/STEMReport.pdf (12/5/2015)

6. Cristobal, E., Flavian, C., Guinaliu, M. (2007), "Perceived e-service quality: measurement validation and effects on consumer satisfaction and web site loyalty", Managing Service Quality, Vol. 17 No. 3, pp. 317-340.

7. Cronin, J.J., Brady, M.K., Hult, G.T.M. (2000), "Assessing the effects of quality, value and customer satisfaction on consumer behavioral intentions in service environments", Journal of Retailing, Vol. 76 No. 2, pp. 193-218.

8. Dado, J., Taborecka Petrovicova, J., Cuzovic, S., Rajic, T. (2012), "An empirical examination of the relationships between service quality, satisfaction and behavioral intentions in higher education setting", Serbian Journal of Management, Vol. 7 No. 2 , pp. 203-218.

9. DeShields Jr., O. W., Kara, A., Kaynak, E. (2005), "Determinants of Business Student Satisfaction and Retention in Higher Education: Applying Herzberg's Two-Factor Theory", International Journal of Educational Management, Vol. 19 No. 2, pp. 128-139.

10. European Commission (2015), „Education and Training Monitor 2015 - Country Analysis", available at: http://ec.europa.eu/education/tools/docs/2015/monitor15country-sheets en.pdf $(1 / 12 / 2016)$

11. Hair, J., Black, W., Babin, B., Anderson, R. (2010), Multivariate Data Analysis, Upper Saddle River, New Jersey, Prentice-Hall. 
12. Ham, L., Hayduk, S. (2003), "Gaining competitive advantages in higher education: analyzing the gap between expectations and perceptions of service quality", International Journal of Value-Based Management, Vol. 16 No. 3, pp. 223-242.

13. Hasan, H. F. A., llias, A., Rahman, R. A., Razak, M. Z. A. (2009), "Service quality and student satisfaction: a case study at private higher education institutions", International Business Research, Vol. 1 No. 3, pp. 163-175.

14. Imrie, B.C., Durden, G., Cadogan, J.W. (2000), "Towards a conceptualization of service quality in the global market arena", Advances in International Marketing, Vol. 10 No. 1, pp. 143-162.

15. Johns, N., Avci, T., Karatepe, O. (2004), "Measuring service quality of travel agents: evidence from Northern Cyprus", The Service Industries Journal, Vol. 24 No. 3, pp. $82-$ 100.

16. Legčević, J. (2014), "Linking higher education and economy as a role for regional development", 3rd International Scientific Symposium Economy of Eastern Croatia Vision and Growth, University J. J. Strossmayer of Osijek, Faculty of Economics in Osijek, pp. 185-194.

17. Lewis, B.R. (1989), "Quality in service sector-a review", International Journal of Brand Marketing, Vol. 7 No. 1, pp. 4-12.

18. Malik, M. E., Danish, R. Q., Usman, A. (2010), "The impact of service quality on students' satisfaction in higher education Institutes of Punjab" Journal of Management Research, Vol. 2 No. 2, pp. 1-11.

19. Marković, S. (2006), "Students' Expectations and Perceptions in Croatian Tourism and Hospitality Higher Education: SERVQUAL versus UNIQUAL", South East European Journal of Economics \& Business, Vol. 1 No. 2, pp. 78-96.

20. Parasuraman, A., Zeithaml, V., Berry, L.L. (1988), "SERVQUAL: a multiple-item scale for measuring customer perceptions of service quality", Journal of Retailing, Vol. 64 No.1, pp. 12-40.

21. Reichheld, F. F. (2003), "The one number you need to grow", Harvard business review, Vol. 81 No. 12, pp. 46-55.

22. Reichheld, F., Sasser Jr., W.E. (1990), "Zero defections: quality comes to services", Harvard Business Review, Vol. 68 No. 5, pp. 105-111.

23. Seng, E. L. K. \& Ling, T. P. (2013), "A Statistical Analysis of Education Service Quality Dimensions on Business School Students' Satisfaction", International Education Studies, Vol. 6 No. 8, pp. 136-146.

24. Swaid, S. (2014), "Service Quality In STEM Higher Education: A Hierarchical Approach", paper presented at International Conference on Learning and Administration in Higher Education, May 21-23, 2014, Nashville, TN, available at: http://iclahe.org/Proceedings/2014/2014-Proceedings.pdf (3/7/2015)

\section{About the author}

Dunja Meštrović, M.Sc. is Head of Student Service Office for Departments of the University of Rijeka, Croatia. Her previous working engagements include the position of Marketing Manager at the Rijekatekstil-domus PLC Rijeka since 2008 and other managing positions at Rijekatekstil-domus PLC (former Domus PLC Rijeka). She earned her M.Sc. and B.Sc. in economics at the University of Rijeka, Faculty of Tourism and Hospitality Management, Opatija, Croatia. She is currently a Ph.D. student of Management of Sustainable development at the University of Rijeka, Faculty of Tourism and Hospitality Management, Opatija, Croatia. The author can be contacted at dmestrovic@uniri.hr. 